\title{
Assessment of Blue Carbon Stock of Mangroves at Malwathu Oya estuary, Sri Lanka
}

\author{
K. A. R. S Perera ${ }^{1 *}$, M. D. Amarasinghe ${ }^{2}$ \\ ${ }^{1}$ Department of Botany, The Open University of Sri Lanka, Sri Lanka \\ ${ }^{2}$ Department of Plant and Molecular Biology, University of Kelaniya, Sri \\ Lanka
}

\section{Abstract}

Mangroves occupy tropical and subtropical inter-tidal areas and provide numerous ecological functions and services. One such function is sequestration of atmospheric carbon, especially in their anoxic soils. This study is an attempt to quantify the total blue carbon stocks in vegetation and in soils of mangrove areas in Malwathu Oya estuary located in the dry/arid climatic zone in Sri Lanka. Plant biomass and the total organic carbon (TOC) content were estimated using allometric relationships available between biomass/TOC and stem diameter of constituent mangrove species. Published data on soil TOC of the same locality was used to estimate the total blue carbon stock associated with this mangrove area. Total biomass of the mangrove plants in Malwathu Oya estuary was $377 \mathrm{Mg}^{\text {ha-1 which }}$ contained $191 \mathrm{Mg} \mathrm{C}^{-1}$ of organic carbon sequestered by the plants. Above ground plant components contained 5 times more biomass and 5.5 times more carbon than those below ground. TOC in the mangrove

\footnotetext{
* Correspondence should be addressed to Dr. K. A. R. S. Perera, Department of Botany, Faculty of Natural Sciences, The Open University of Sri Lanka.
}

Email:kaper@ou.ac.lk

https://orcid.org/0000-0003-3387-8146

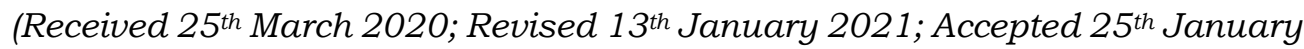
2021 (C) OUSL)

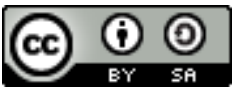

This article is published under the Creative Commons Attribution-Share Alike 4.0 International License (CC-BY-SA). This license permits use, distribution and reproduction in any medium; provided it is licensed under the same terms and the original work is properly cited. 
soils was $346 \mathrm{Mg} \mathrm{C}^{-1}$ which was 1.8 times more than that in the vegetation. Total blue carbon stock of the mangrove ecosystem in Malwathu Oya estuary therefore was $537 \mathrm{Mg} \mathrm{C} \mathrm{ha-1}^{-1}$, out of which $64 \%$ was sequestered in soils. Despite being in low rainfall coast this mangrove area retains more carbon than most other areas which may be possibly due to its pristineness and vegetation structure characterized by unique dominance of Sonneratia alba, which is considered a rare species among Sri Lankan mangroves.

Keywords: carbon retention capacity; plant biomass; soil carbon; Sri Lankan mangroves

\section{Introduction}

Mangrove forests are characterized as unique and complex coastal ecosystems in the tropical and sub-tropical regions of Sri Lanka. They line the coasts of the oceans between approximately $30^{\circ} \mathrm{N}$ and $30^{\circ} \mathrm{S}$ latitude (Spalding et al., 2010; Giri et al., 2011) and are the source of several ecosystem services. High primary productivity compared to other terrestrial plant communities (Donato et al., 2011) renders mangroves a great potential in contributing to carbon sequestration function (Kathiresan, 2007; Suratman, 2008; Khan et al., 2009; Alongi, 2011). It has been proven that mangroves represent a potentially important repository of blue carbon, thus they have been ranked among the most carbon-dense forests in the tropics, due to its deep organic carbon-rich soils and dense vegetation (Donato et al., 2011; Kauffman et al., 2011). Mangroves are not only a carbon-rich ecosystem but also are proven to be of high potential in capturing and sinking significant amounts of atmospheric carbon, thus compensating for negative impacts of anthropogenic greenhouse gas (GHG) emissions (McLeod et al., 2011; Siikamaki et al., 2012; Murdiyarso et al. 2020, Howard et al., 2017; Perera \& Amarasinghe, 2016). As such, mangroves and other coastal wetlands (with "blue carbon" deposits) can potentially play a crucial role in climate change mitigation (Price \& Warren, 2016).

More recent estimates of global mangrove distribution range from 12 to 20 million ha with spreading over 113 countries (FAO, 2003) with 55 species of true mangrove plants (Tomlinson, 2016). The current 
extent of mangroves in Sri Lanka is 19,000 ha (unpublished records of the Department of Forest Conservation) and these areas support 23 true mangrove species and 34 mangrove associated plant species (Amarasinghe \& Perera, 2017). Despite the relatively low extent, distribution of species among mangrove ecosystems in Sri Lanka is ecologically intrigued. Mangroves in Malwathu Oya estuary are visually dominated by Sonneratia alba, a species considered to be rare and endangered in Sri Lanka. This is the only locality where S. alba occurs as a dominant species in the water-front zone of a mangrove stand with individual plants reaching up to $75 \mathrm{~cm}$ in diameter. Besides, this estuarine mangrove area is in a very remote part of Sri Lanka, where human interference is negligible, for which the size of plants/trees provide testimony. Objective of the present study, therefore, was to determine the blue carbon stocks of this relatively pristine mangrove area dominated by a mangrove species that is uncommon in other coastal areas of Sri Lanka.

\section{Materials and Methodology}

\section{Study area}

Malwathu Oya estuary is located between $8^{\circ} 47^{\prime}-8^{\circ} 49^{\prime} \mathrm{N}$ and $79^{\circ} 55^{\prime}$ - $79^{\circ} 56^{\prime} \mathrm{E}$, on the north western coast of Sri Lanka and belongs to the North-Western province and Mannar District. Malwathu Oya estuary lies in the arid climatic zone of Sri Lanka (Fig. 1).

The estuary created the discharge of the Malwathu Oya, which has the second largest catchment in Sri Lanka, i.e., approximately 3264 $\mathrm{km}^{2}$, and discharges 196 million cubic meters of water to the sea annually (Survey Department of Sri Lanka, 2007). The soils of the area are alluvial (IUCN, 2011). An arid climate prevails in the area where the annual rainfall is $700-1000 \mathrm{~mm}$, of which $60-70 \%$ occurs during the north east monsoon from October to April. The mean atmospheric temperature ranges from $25^{\circ} \mathrm{C}-29^{\circ} \mathrm{C}$ with higher temperatures normally recorded between May and August. 

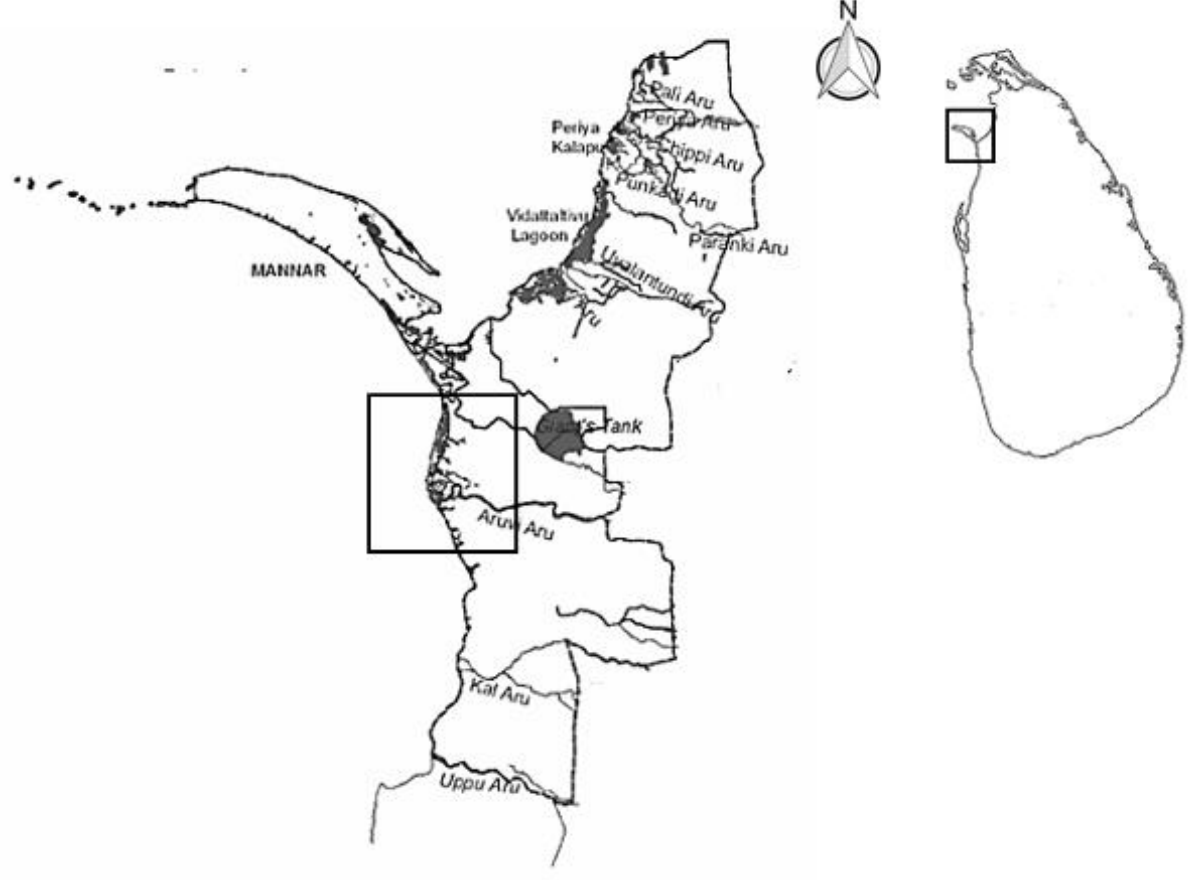

Figure1: Location of the study area

Being a dry climatic area, the mangroves are associated with salt marshes and species of other terrestrial vegetation such as woody scrub jungles, sand dunes and strand vegetation are found as associated species. Although, current extent of mangroves around associated with Malwathu Oya estuary is unavailable, the total mangrove extent of the Mannar District was reported to be 1351 ha (Edirisinghe et al., 2012).

\section{Field Sampling}

Four (4) sampling sites were selected within the mangrove areas of the Malwathu Oya estuary to collect data on vegetation structure and total organic carbon (TOC) content in soil. In each sampling site, $10 \mathrm{~m}$ wide belt transects were laid perpendicular to the shoreline at randomly selected locations. Length of the transect was determined on the width of the mangrove vegetation. Each transect was divided into $10 \mathrm{~m} \times 10 \mathrm{~m}\left(100 \mathrm{~m}^{2}\right)$ sampling plots and a total of thirteen (13) sampling plots were laid in all four sampling sites. 


\section{Species composition and vegetation structure}

Data on mangrove vegetation structure i.e., species diversity, plant density, tree diameter at breast height $(\mathrm{dbh})$ and tree height were measured using standard methods (Cintron \& Novelli, 1984; Kathiresan \& Khan, 2010) with plants in each sampling plot $\left(100 \mathrm{~m}^{2}\right)$. Trees which are equal to or greater than $2.5 \mathrm{~cm}$ in dbh were measured for the purpose.

Structural complexity (CI) of the vegetation (Kathiresan $\&$ Khan, 2010) was calculated using data on the number of species, stand density, basal area and height, to represent the overall vegetation structure. Structural complexity $(\mathrm{CI})=$ Number of species $\mathrm{x}$ stand density $\mathrm{x}$ stand basal area $\mathrm{x}$ stand height $\mathrm{x} 10^{-5}$

Importance value index (IVI) was calculated for each constituent species to represent the relative contribution of constituent species to complexity of total vegetation structure using the following relationship

IVI of a species $=$ Relative density + Relative dominance (basal area) + Relative frequency

\section{Biomass and total organic carbon (TOC) content in above and below ground components of mangrove vegetation}

Above ground biomass (AGB) and below ground biomass (BGB) of mangrove species present in sampling plots were estimated by using the allometric relationships, $\log _{e}(A G B)=6.247+2.64 \log _{e}(d b h)$ and $\log _{\mathrm{e}}(\mathrm{AGB})=5.551+2.153 \log _{\mathrm{e}}(\mathrm{dbh})$ to determine above ground biomass of Rhizophora mucronata and Avicennia marina respectively (Amarasinghe \& Balasubramaniam, 1992). Common equations, i.e., $\mathrm{AGB}=0.251 \rho \mathrm{dbh}^{2.46}$ and $\mathrm{BGB}=0.199 \rho 0.899 \mathrm{dbh}^{2.46}(\rho-$ density of wood) (Komiyama et al., 2005), were used to calculate the above and below ground biomass of all the other species encountered in the sample plots.

Biomass values (above and below ground biomass) mangrove species were then converted to the total organic carbon (TOC) content with the percentage TOC content in biomass of each mangrove plant component (Perera \& Amarasinghe, 2016). 


\section{Total organic carbon (TOC) storage in mangrove soil}

Published data on total organic carbon (TOC) content retained in each depth, $0-15 \mathrm{~cm}, 16-30 \mathrm{~cm}$ and $31-45 \mathrm{~cm}$ of its soils (Perera \& Amarasinghe, 2019) were used to calculate the magnitude of total blue carbon stock of Malwathu Oya estuarine mangrove ecosystem.

\section{Results}

\section{Structure of mangrove vegetation}

Stand density values recorded in the study sites ranged between 2550 - 4833 trees/ha. Higher relative frequency values recorded for Rhizophora mucronata, Avicenna marina, Sonneratia alba and Excoecaria agallocha revealed those were the most abundant mangrove species in the area (Table 1).

Table 1: Vegetation structural variables recorded at Malwathu Oya estuary

\begin{tabular}{|c|c|c|c|c|c|}
\hline 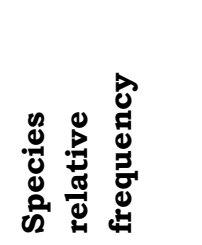 & 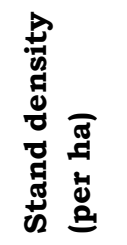 & 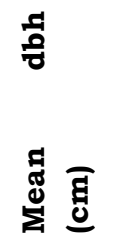 & 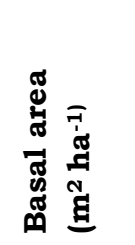 & 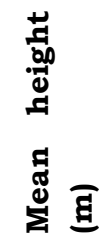 & 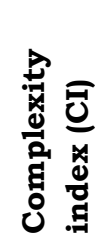 \\
\hline $\begin{array}{l}\mathrm{AM}(27.5 \%) ; \\
\mathrm{EA}(13.3 \%) ; \\
\mathrm{PA}(2.5 \%) ; \\
\mathrm{RM}(43.2 \%) ; \\
\mathrm{SA}(14.4 \%)\end{array}$ & $\begin{array}{l}3808 \\
\pm 1766 \\
(2552- \\
4833)\end{array}$ & $\begin{array}{l}9.25 \\
(6.21- \\
14.51)\end{array}$ & $\begin{array}{l}32.22 \\
(18.13- \\
43.38)\end{array}$ & $\begin{array}{l}4.86 \\
(4.0- \\
6.02)\end{array}$ & $\begin{array}{l}23.94 \\
(5.42- \\
42.46)\end{array}$ \\
\hline
\end{tabular}

(AM-Avicennia marina; EA-Excoecaria agallocha; RM-Rhizophora mucronata; SA-Sonneratia alba)

Sonneratia alba trees were larger in diameter and taller than other species. The average size of Rhizophora mucronata plants was smaller than S. alba, nevertheless, occurred in high density (1382 trees per ha), making it the species that contributes most to the overall structure of the vegetation (with an IVI of 82.25), even in the presence of larger trees of S. alba in the vegetation (Table 2). 
Table 2: Structural data of constituent species of Malwathu Oya estuarine mangroves

\begin{tabular}{|c|c|c|c|c|c|}
\hline $\begin{array}{l}\text { Mangrove } \\
\text { species }\end{array}$ & $\begin{array}{l}\text { Density } \\
\text { (No. } \\
\text { Trees } \\
\text { per ha) }\end{array}$ & $\begin{array}{l}\text { Mean basal } \\
\operatorname{area}\left(\mathrm{m}^{2} / \mathrm{ha}\right)\end{array}$ & $\begin{array}{l}\text { Mean } \\
\text { height } \\
(\mathrm{m})\end{array}$ & $\begin{array}{l}\text { Total } \\
\text { biomass } \\
\text { (Mg/ha) }\end{array}$ & IVI \\
\hline $\begin{array}{l}\text { Avicennia } \\
\text { marina }\end{array}$ & $\begin{array}{l}882 \\
\pm 221\end{array}$ & $7.31 \pm 0.05$ & $\begin{array}{l}4.51 \\
\pm 0.04\end{array}$ & $\begin{array}{l}79.59 \\
\pm 0.89\end{array}$ & 93.95 \\
\hline $\begin{array}{l}\text { Excoecaria } \\
\text { agallocha }\end{array}$ & $\begin{array}{l}427 \\
\pm 102\end{array}$ & $1.67 \pm 0.01$ & $\begin{array}{l}4.21 \\
\pm 0.03\end{array}$ & $\begin{array}{l}7.81 \\
\pm 0.82\end{array}$ & 30.77 \\
\hline $\begin{array}{l}\text { Pemphis } \\
\text { acidula }\end{array}$ & $82 \pm 20$ & $0.29 \pm 0.00$ & $\begin{array}{l}6.31 \\
\pm 0.46\end{array}$ & $\begin{array}{l}3.47 \\
\pm 0.04\end{array}$ & 14.79 \\
\hline $\begin{array}{l}\text { Rhizophora } \\
\text { mucronata }\end{array}$ & $\begin{array}{l}1382 \\
\pm 340\end{array}$ & $4.47 \pm 0.03$ & $\begin{array}{l}4.48 \\
\pm 0.29\end{array}$ & $\begin{array}{l}46.22 \\
\pm 0.52\end{array}$ & 82.25 \\
\hline $\begin{array}{l}\text { Sonneratia } \\
\text { alba }\end{array}$ & $427 \pm 98$ & $12.81 \pm 0.10$ & $\begin{array}{l}6.36 \\
\pm 0.05\end{array}$ & $\begin{array}{l}187.73 \\
\pm 2.12\end{array}$ & 78.21 \\
\hline
\end{tabular}

Structural variables of mangroves at Malwathu Oya estuary, were analyzed across the gradient from estuarine shoreline towards the land. The highest stand density and the relevant basal area were observed as being near the water-front zone of this mangrove area (Fig. 2). The highest relative contribution to the total organic carbon pool in the vegetation is by S. alba (Fig. 3) 


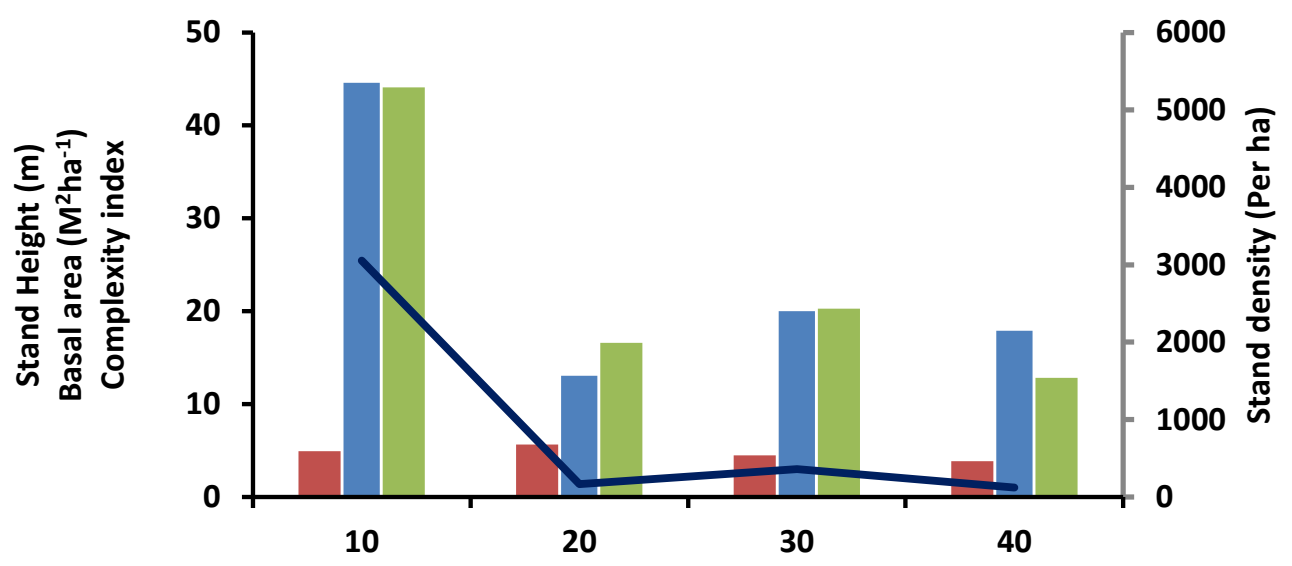

Distance from shoreline $(\mathrm{m})$

STAND HEIGHT(M)

BASAL AREA M2 ha-1

Figure 2: Vegetation structural variables vary with the distance from the estuarine shoreline

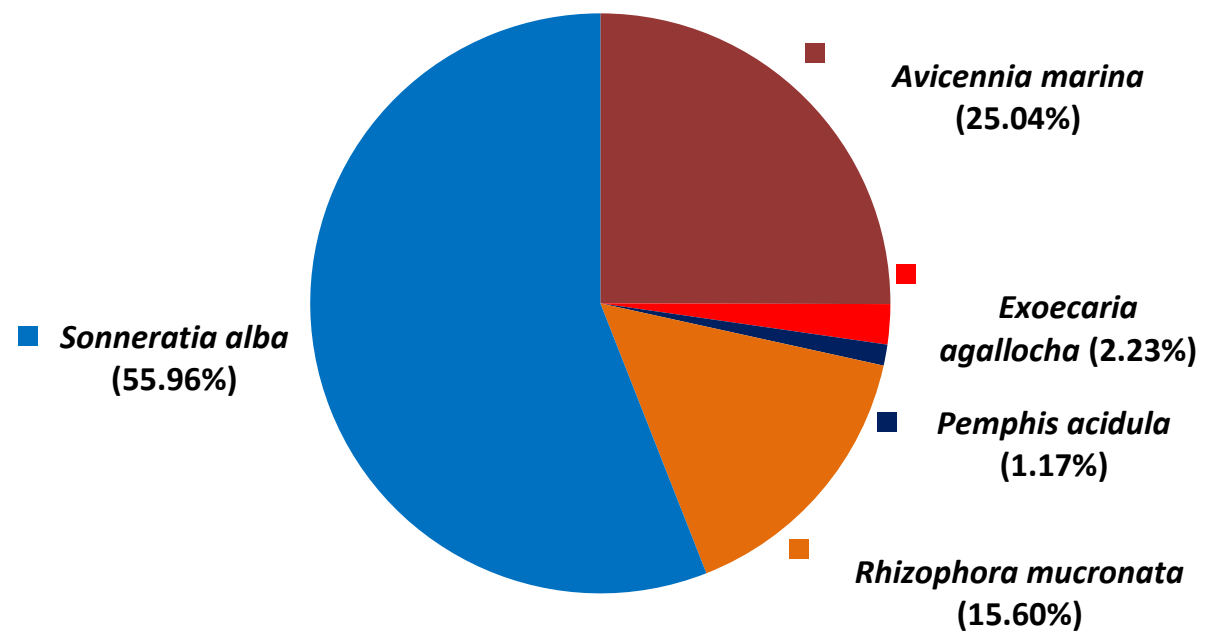

Figure 3: Percentage contribution of mangrove species to the carbon retention capacity of the mangrove areas at the Malwathu Oya estuary 
The amount of carbon retained (blue carbon content) in plant biomass declines while that in the soil increases along the water-land gradient in Malwathu Oya estuarine mangrove areas. The overall magnitude of blue carbon stocks along the same gradient manifests an increasing tendency (Fig. 4)

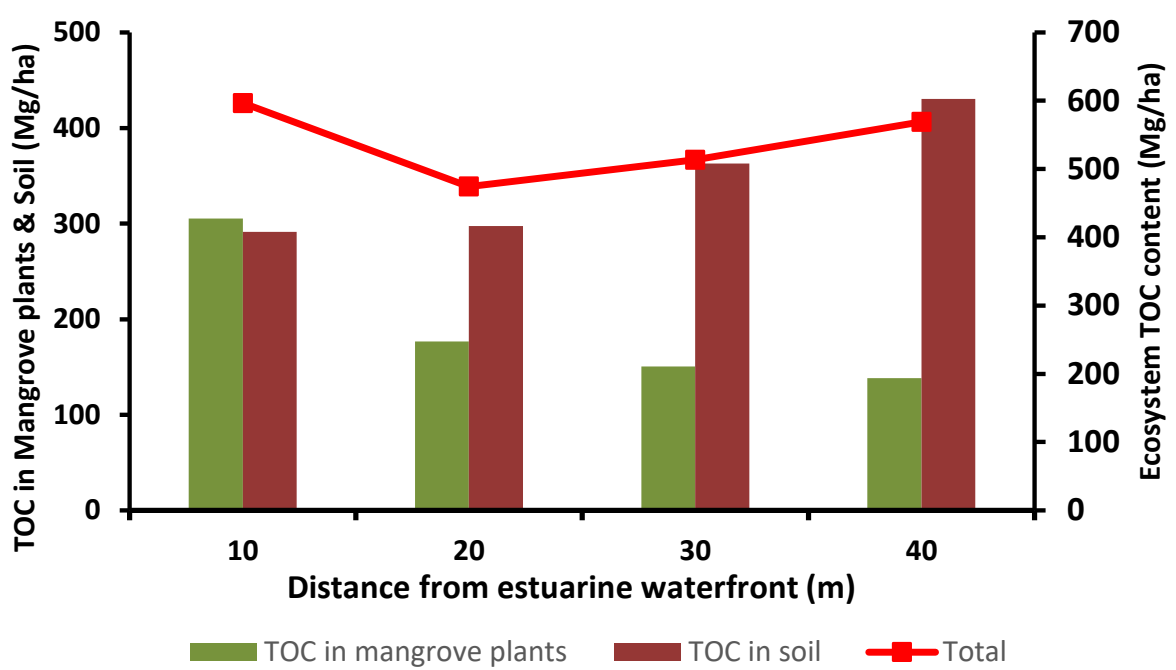

Figure 4: Variation in blue carbon content along the water-land gradient in Malwathu Oya estuary

The stock of blue carbon retained by the mangrove ecosystem was $536.95 \mathrm{Mg} \mathrm{C}^{-1}$. Mangrove soil contained 64\% (345.54 $\mathrm{Mg} \mathrm{C}^{-1}$ ) of the TOC stock while $30 \%\left(162.17 \mathrm{Mg} \mathrm{C}^{-1}\right)$ was in above ground and $5 \%\left(29.97 \mathrm{Mg} \mathrm{C}^{-1}\right)$ in the below ground components of mangrove plants (Table 4). 
Table 4: Estimated total blue carbon content in the mangrove ecosystem at Malwathu Oya estuary

\begin{tabular}{|c|c|c|}
\hline \multirow{3}{*}{$\begin{array}{l}\text { TOC in Mangrove } \\
\text { plants }\left(\mathrm{Mg} \mathrm{C} \mathrm{ha-1)}^{-1}\right.\end{array}$} & $\begin{array}{l}\text { Above ground } \\
\text { components }\end{array}$ & $162.17 \pm 9.20(30.20 \%)$ \\
\hline & $\begin{array}{l}\text { Below ground } \\
\text { components (roots) }\end{array}$ & $29.27 \pm 1.57$ (5.45\%) \\
\hline & Total & $191.41 \pm 10.77$ (35.64\%) \\
\hline \multicolumn{2}{|c|}{$\begin{array}{l}\left.\text { TOC in Mangrove soil (Mg C ha }{ }^{-1}\right) \\
\text { (Source: Perera and Amerasinghe, 2019) }\end{array}$} & $345.54 \pm 18.06(64.46 \%)$ \\
\hline \multicolumn{2}{|l|}{ Total (Mg C ha-1) } & $536.95 \pm 29.02$ \\
\hline
\end{tabular}

\section{Discussion}

Mangrove species richness in the Malwathu Oya estuarine mangrove ecosystem is relatively low compared to mangrove areas in the wet zone of Sri Lanka (de Sliva \& de Silva, 1989; Jayatissa et al., 2002; Amarasinghe \& Perera, 2017). High soil salinities characteristic to arid coastal areas consequential of low rainfall and high evapotranspiration rates restrict the presence of mangrove species that are well adapted to hypersaline soils. Sonneratia alba is the most dominant species, having the highest contribution to blue carbon stock of Malwathu oya estuarine mangrove ecosystem. It generally inhabits low intertidal zones of downstream estuarine systems and it is one of the superior salt tolerant mangrove species. It reaches an optimal growth in 5 to $50 \%$ seawater, indicating its capacity to tolerate high salinity and hypoxia (Ball \& Pidsley, 1995).

Heterogeneity in vegetation structure and distribution of biomass per unit area, along the water-land gradient in Malwathu Oya mangroves was observed to be a pattern, i.e., the highest structural diversity and biomass at the water-front zone that gradually diminishes towards land, similar to that exists in the mangrove areas of Negombo estuary (Perera \& Amarasinghe 2016), Uppar lagoon and the Batticaloa lagoon (Perera \& Amarasinghe 2014) in Sri Lanka. Availability of river-borne nutrients, favorable salinity regimes and optimal seed rain in the water-front zone may potentially contribute to this pattern. The micro- 
tidal conditions prevailing in coastal waters around Sri Lanka (Pattiaratchi \& Wijeratne, 2009) that is not conducive to have frequent inundations of the landward zones of mangrove areas may contribute to this situation.

The above ground biomass (317.43 $\mathrm{Mg} \mathrm{ha}^{-1}$ ) and the TOC content (162.17 $\mathrm{Mg} \mathrm{C} \mathrm{ha}^{-1}$ ) of mangrove plants estimated in the present study were found to be higher than the average biomass values available for South East Asia (Hutchison et al., 2014; IPCC, 2013). Plant biomass represents the potential amount of total organic carbon (TOC) content retained by them. Nearly $70 \%$ of the total mangrove biomass reported to occur in mangrove vegetation are retained by those located within 00 to $10^{\circ}(\mathrm{N} / \mathrm{S})$ latitudes. The average above ground biomass of mangroves ranges from $283.6 \mathrm{Mg} \mathrm{ha}^{-1}$ near the equator (tropical), to $104.2 \mathrm{t} \mathrm{ha}^{-1}$, in areas within $30^{\circ}$ to $40^{\circ}$ (N/S) (sub- tropical) zones (Twilley, 1992). Sri Lanka being located within the tropical belt which receives the highest quantum of solar energy throughout the year and rainfall provides conducive environment for primary production that results in greater amounts of biomass where atmospheric carbon is sequestered.

Mangrove soils of Malwathu Oya estuary retains nearly $64 \%$ of the total blue carbon stock of $536 \mathrm{Mg} \mathrm{C}^{-1}$, highlighting the significance of its contribution to total carbon sequestration capacity of this mangrove ecosystem. This is a higher amount than that is reported (511 $\mathrm{Mg} \mathrm{C} \mathrm{ha-1)} \mathrm{by} \mathrm{the} \mathrm{Intergovernmental} \mathrm{Panel} \mathrm{on} \mathrm{Climate} \mathrm{Change}$ (IPCC) for mangroves in 2013 and the average soil carbon pools of upland forests that ranges from $83 \mathrm{Mg} \mathrm{C}^{-1} \mathrm{~h}^{-1}$ in dry forests to $210 \mathrm{Mg}$ $\mathrm{C}$ ha $^{-1}$ in tropical rain forests (Kauffman et al., 2011). Our results also revealed that the increasing magnitude of total blue carbon stocks along the water-land gradient, is primarily contributed by the increasing soil carbon content across the gradient, rather than the organic carbon in biomass of the vegetation. Organic carbon in mangrove soils may derive from both the primary production and litterfall of mangroves (autochthonous) and the river-borne organic matter produced by terrestrial ecosystems (allochthonous). Owing to the high primary productivity characteristic to mangroves and the relatively low rainfall of the Malwathu Oya catchment, coupled with 
micro-tidal coastal waters, the autochthonous fraction of the soil carbon pool may dominate in this estuarine mangrove area.

The near-pristine mangrove areas in the Malwathu Oya estuary, therefore, retain a significant stock of blue carbon, especially in the soil. Remoteness of this locality and poor accessibility to this area during the recent past due to civil unrest which prevailed in these areas may have kept human interference at bay. Despite the low extent, mangrove areas in the Malwathu Oya estuary deserve conservation as a refugium for $S$. alba, which is reckoned as a rare mangrove species in Sri Lanka, and their noteworthy capacity to sequester atmospheric carbon as well as for the production (particulate and dissolved organic matter) and nursery functions that mangrove areas are proven to contribute (Lee et al, 2014).

Quantification of sequestered carbon stocks within ecosystems has become a requirement under the current context where market-based mechanisms to address climate change issues have gained popularity. Carbon trading strategies initiated by the United Nation's REDD+ (Reducing Carbon Emissions from Deforestation and Forest Degradation) demands quantification of sequestered carbon stocks to value them and other ecosystem services that these forests/ ecosystems generate, to provide financial incentives to reduce deforestation (when forests are converted to other uses, such as agriculture), reduce degradation (when forests lose their ability to provide ecosystems services) and to promote their sustainable management that ensures social, ecological and economic benefits for future generations.

\section{References}

Alongi, D. M. (2011). Carbon payments for mangrove conservation: ecosystem constraints and uncertainties of sequestration potential. Environmental Science and Policy, 14(4), 462-470. https://doi.org/10.1016/j.envsci.2011.02.004.

Amarasinghe, M. D. \& Balasubramaniam, S. (1992). Structural properties of two types of mangroves stands on the northern 
western coast of Sri Lanka. Hydrobiologia, 247, 17-27. https://doi.org/10.1007/BF00008201.

Amarasinghe, M. D. \& Perera, K. A. R. S. (2017). Historical biogeography of mangroves in Sri Lanka. Ceylon Journal of Science, (Special Issue) 46, 111-117. http://doi.org/10.4038/cjs.v46i5.7458.

Ball M. C, \& Pidsley S. M. (1995). Growth responses to salinity in relation to distribution of two mangrove species, Sonneratia alba and S. lanceolata, in northern Australia. Funct Ecol., 9, $77-85$.

Cintron, G. \& Schaeffer-Novelli, S. Y. (1984). Methods for studying mangrove structure, In: Snedaker, S. C. \&Snadaker, J. (Eds.), The mangrove ecosystem: research methods, UNESCO, Paris, 91-113.

De Silva, M. \& de Silva, P. K. (1989). Status, diversity and conservation of the mangrove forests of Sri Lanka, Journal of South Asian natural History, 3(1), 79-102.

Donato, D., Kauffman, J. B., Murdiyarso, D., Kurnianto, S., Stidham, M. \& Kannien, M. (2011). Mangroves among the most carbonrich forests in the tropics. Nature Geoscience, 4, 293-297. https://doi.org/10.1038/ngeo1123.

Edirisinghe, E. A. P. N., Ariyadasa, K. P. and Chandani, R. P. D. S. (2012). Forest Cover Assessment of Sri Lanka. The Sri Lankan Forester (New series), 34, 1-12.

FAO (2003). Status and trends in mangrove area extent worldwide. Wilkie, M.L., Fortuna, S. (Eds.). Forest Resources Assessment Working Paper No. 63. Forest Resources Division. FAO, Rome. (Unpublished).

Giri, C. E., L., Ochieng, L. L., Tieszen, Z., Zhu, A., Singh, T., Loveland, J. Masek. \& Duke, N. (2011). Status and distribution of mangrove forests of the world using Earth observation satellite data. Global Ecology and Biogeography, 20,154-159.

Hutchison, J., Manica, A., Swetnam, R., Bamford, A. \& Spalding, M. (2014). Predicting Global Patterns in Mangrove Forest Biomass. Conservation Letters, 7(3), 233-240. doi: 10.1111/conl.12060. 
Howard, J., Sutton-Grier, A., Herr, D., Kleypas, J., Mcleod, E., Pidgeon, E. \& Simpson, S. (2017). Clarifying the role of coastal and marine systems in climate mitigation. Frontiers in Ecology and Environment. https://doi.org/10.1002/fee.1451.

IPCC (2013). Coastal Wetlands, Chapter 4, Wetlands Supplement (Draft Report).

IUCN (2011). Biodiversity and Socio-economic Information of selected areas of Sri Lankan side of the Gulf of Mannar: Report submitted by IUCN Sri Lanka Country Office to BOBLME Project Component 2.4 Collaborative Critical Habitat Management: Gulf of Mannar. IUCN Sri Lanka country Office, Colombo.

Jayatissa, L. P., Dahdouh-Guebas, F. \& Koedam, N. (2002). A review of floral composition and distribution of mangroves in Sri Lanka. Botanical Journal of the Linneas Society, 138, 29-43.

Kathiresan, K. (2007). Rehabilitation of destroyed mangrove forests as a carbon and nutrient sink, Tateda et al., (Eds), Greenhouse gas and carbon balances in mangrove coastal ecosystems, Maruzen, Tokyo, Japan, 249-257.

Kathiresan, K. \& Khan, S. A. (2010). International Training Course on Costal biodiversity in Mangroves: Course manual, Annamalie University (CAS in Marine Biology, Parangipettai), India, 744.

Kauffman, J. B., Heider, C., Cole, C. T., Dwyer, K. \& Donato, D. C. (2011). Ecosystem carbon stocks of Micronesian mangrove forests, Wetlands, 31, 343-352.

https://doi.org/10.1007/s13157-011-0148-9.

Murdiyarso, D., Simpson, L. \& Hernandez Trejo, H. (2020). Total ecosystem carbon stocks of mangroves across broad global environmental and physical gradients. Ecological Monographs 00(00): e01405. 10.1002/ecm. 1405.

Khan, N. I., Suwa, R. \& Hagihara, A. (2009). Biomass and aboveground net primary production in a subtropical mangrove stand Kandelia obovata (S.L.) Yong at Manko wetland, Okinawa, Japan, Wetlands Ecology \&Management, 17, 585-599. https://doi.org/10.1007/s11273-009-9136-8. 
Komiyama, A., Poungparn, S. \& Kata, S. (2005). Common allometric equations for estimating the tree weight of mangroves, Journal of Tropical Ecology, 21, 471-477. https://doi.org/10.1017/S0266467405002476

McLeod, K. W., Chmura, G. L., Bouillon, S., Salm, R., Bjork, M., Duarte, C. M., Lovelock, C. E., Schlesinger, H. \& Silliman, B. R. (2011). A blueprint for blue carbon: toward an improved understanding of the role of vegetated coastal habitats in sequestering $\mathrm{CO} 2$. Frontiers in Ecology and the Environment, 9, $552-560$.

Lee, S. Y., Primavera, J. H., Dahdouh-Guebas, Farid \& McKee, Karen L. (2014). Ecological role and services of tropical mangrove ecosystems: A reassessment. DOI: 10.1111/geb.12155.

Pattiaratchi, C. B. \& Wijeratne, E. M. S. (2009). Tide Gauge Observations of 2004-2007 Indian Ocean Tsunamis from Sri Lanka and Western Australia. Pure and Applied Geophysics, 166, 233-258. DOI 10.1007/s00024-008-0434-5.

Perera, K. A. R. S. \& Amarasinghe, M. D. (2014). Effect of Vegetation Structure on Carbon Assimilation Capacity of Mangrove Ecosystems in the East Coast of Sri Lanka. Journal of Coastal Development, 17, 1410-5217. http://dx.doi.org/10.4172/ 1410-5217.1000382.

Perera, K. A. R. S. \& Amarasinghe, M. D. (2016). Atmospheric carbon removal capacity of a mangrove ecosystem in a micro-tidal basin estuary in Sri Lanka, Journal of Atmospheric Environment, 134, 121-128. https://doi.org/10.1016/j.atmosenv.2016.03.034

Perera, K. A. R. S. \& Amarasinghe. M. D. (2019). Carbon sequestration capacity of mangrove soils in micro tidal estuaries and lagoons: A case study from Sri Lanka. Geoderma, 347, 80-89 https://doi.org/10.1016/j.geoderma.2019.03.041.

Price, J. T. \& Warren, R. F. (2016). Review of the potential of "blue carbon" activities to reduce emissions. 1104872/AVOID2 WPE.2 Report 1. http:/ / avoid-netuk.

Siikamaki, J., Sanchirico, J. N. \& Jardine, S. L. (2012). Global economic potential for reducing carbon dioxide emissions from 
mangrove loss. Proceedings of the National Academy of Sciences USA, 109, 14369-14374.

Spalding, M. D., Kainuma, M. \& Collins, L. (2010). World atlas of mangroves. Earthscan, London, UK.

Suratman, M. N. (2008). Carbon sequestration potential of mangroves in southeast Asia. In: F. Bravo et al. (Eds.), Managing Forest ecosystems: The challenge of climate change, Springer Science Business media, 297-315. https://doi.org/10.1007/978-14020-8343-3_17.

Survey Department of Sri Lanka (2007). The National Atlas of Sri Lanka. Survey Department, Sri Lanka. 2nd edition.

Tomlinson P. B. (2016). The Botany of Mangroves. 2. Cambridge University Press, 436.

Twilley, R. R., Chen, R. H. \& Hargis, T. (1992). Carbon sinks in mangrove forests and their implications to the carbon budget of tropical coastal ecosystems, Water Air and Soil Pollution, 64, 265-288. https://doi.org/10.1007/BF00477106. 